\title{
Flow of nitrogen from the rumen and abomasum in cattle and sheep given protein-free nutrients by intragastric infusion
}

\author{
BY E. R. ØRSKOV, N. A. MACLEOD AND D. J. KYLE \\ Rowett Research Institute, Bucksburn, Aberdeen AB2 9SB
}

(Received 20 March 1985 - Accepted 10 February 1986)

\begin{abstract}
1. Three experiments were conducted to determine the flow of nitrogen through the rumen and abomasum when cows, steers and lambs were totally nourished on volatile fatty acids infused into the rumen.

2. In two dairy cows $(650-700 \mathrm{~kg})$ and two large steers $(370-405 \mathrm{~kg})$ the daily flow of non-ammonia-N (NAN) from the rumen was 50.7 and $58 \mathrm{mg} / \mathrm{kg}$ live weight $(\mathrm{W})^{0.75}$ respectively.

3. The flows of NAN through the rumen and abomasum in four young steers $(240-315 \mathrm{~kg})$ were 85.0 (SE 21.0$)$ and $195(\mathrm{SE} 7 \cdot 0) \mathrm{mg} / \mathrm{kg} \mathrm{W}^{0 \cdot 75}$ respectively.

4. In the third experiment the effects of altering rumen $\mathrm{pH}$ and osmotic pressure on flow of NAN through the rumen and abomasum were investigated in lambs. While rumen $\mathrm{pH}$ and osmotic pressure influenced rumen volume and outfiow they had no significant effect on NAN flow. The mean values for NAN outflow from the rumen and abomasum were 76 and $181 \mathrm{mg} \mathrm{N} / \mathrm{kg} \mathrm{W}^{0 \cdot 75}$ respectively.

5. Abomasal NAN flow increased with increasing abomasal $\mathrm{pH}$. When osmotic pressure was greater than about $330 \mathrm{mosmol} / \mathrm{l}$ in the rumen there was a net inflow of water, while below this value there was net loss of water.

6. For all experiments the flow of $\mathrm{N}$ both from the rumen and abomasum was highly variable; this has to be considered if a constant value is used for endogenous $\mathrm{N}$ in estimating dietary $\mathrm{N}$ in the abomasum.

7. With $\mathrm{N}$-free infusion the rumen $\mathrm{NH}_{3}$ concentration varied from 50 to $120 \mathrm{mg} \mathrm{NH}-\mathrm{N} / \mathrm{l}$.

8. The amino acid composition of rumen and abomasal $\mathrm{N}$ was also determined. Relative to tissue $\mathrm{N}$ it contained a higher proportion of cysteine.
\end{abstract}

Measurement of the flow of nitrogen at the duodenum is generally used to gain information, in ruminants, on the protein presented for absorption in the small intestine, and this information has in turn been used in part to construct new systems of protein evaluation (Agricultural Research Council, 1980, 1984; Institut National de la Recherche Agronomique, 1978) for ruminants.

The $\mathrm{N}$ in the abomasum originates from different sources. Generally the greatest fraction consists of microbial protein formed during the fermentation of carbohydrate in the rumen, while another fraction of varying proportion consists of undegraded dietary protein. The relative sizes of the fractions depend largely on the rumen degradability of the dietary protein (Ørskov, 1982). A further fraction derives from endogenous protein contained in enzymes secreted into the abomasum and from sloughed epithelial cells from the respiratory tract, mouth, oesophagus and rumen wall. The latter fraction may already be partially degraded by rumen microbes in the contents of the rumen and by bacteria adherent to the rumen wall (Wallace et al. 1979) before it enters the abomasum, but quantitative measurements have always presented difficulties. A value derived by Clarke et al. (1966) of about $1.2 \mathrm{~g} / \mathrm{d}$ for the endogenous $\mathrm{N}$ of sheep is often subtracted from the total abomasal $\mathrm{N}$ rather than attempting to determine it directly in order to calculate the undegraded dietary fraction (Agricultural Research Council, 1980).

The development of the technique of intragastric nutrition (Ørskovet al. 1979; MacLeod et al. 1982) has made it possible to sustain animals on protein-free nutrients and to obtain measurements of endogenous $\mathrm{N}$ uncomplicated by microbial and dietary contributions. Measurements, under these conditions, can be made of endogenous $\mathrm{N}$ from enzyme sources and from epithelial cells. While the validity of using this technique to arrive at estimates of endogenous contributions may be questioned, the mitotic index of rumen epithelial tissue 
is similar to that of normally fed animals (Dinsdale et al. 1980). It is also possible that the total abomasal secretion of $\mathrm{N}$ may be greater in the normally fed animal, so that the secretion determined here may be a minimal one. The determinations were made in cows, steers and lambs. Some observations have been published (Ørskov \& MacLeod, $1982 b$, 1983).

\section{MATERIALS AND METHODS}

\section{Expt 1}

Animals and treatments. Two dry and pregnant Friesian dairy cows $(650-700 \mathrm{~kg})$ fitted with rumen cannulas and abomasal catheters were used on two occasions. Before the measurement of endogenous flow of $\mathrm{N}$ they were kept on infusion for 2 months for measurements of $\mathrm{N}$ balance (Ørskov \& MacLeod, 1982a). Details of the surgical preparation of the animals, the method of infusion of nutrients, and the techniques used to monitor the health of the animals and control of infusions were as described by MacLeod et al. (1982). After $4 \mathrm{~d}$ on protein-free infusions at a gross energy level of $450 \mathrm{~kJ} / \mathrm{kg}$ live weight $(\mathrm{W})^{0 \cdot 75}$, a pulse dose of $100 \mathrm{~g}$ polyethylene glycol (molecular weight $4000 ; \mathrm{PEG}$ ) in solution was injected through the cannula into the rumen using a syringe and catheter. The PEG was thoroughly mixed into the rumen contents. Fluid samples were then removed at half-hourly intervals over the first $2 \mathrm{~h}$ followed by samples at intervals of time widening from $1.5 \mathrm{~h}$ to $4 \mathrm{~h}$. In all, thirteen samples were removed over a period of $31 \mathrm{~h}$ to estimate rumen volume and the fractional rate of liquid outflow (FRO) from the decline in rumen PEG concentrations. Simultaneous samples were obtained for the estimation of ammonia and total $\mathrm{N}$ flow.

Two steers similarly prepared with rumen cannulas and abomasal catheters were used on two occasions separated by 4 months. Their live weights were between 370 and $405 \mathrm{~kg}$. They had previously been used in trials to measure the endogenous urinary $N$ and had been on $\mathrm{N}$-free nutrients for $4 \mathrm{~d}$ before measurement of endogenous $\mathrm{N}$ flow. The level of energy infused was calculated to supply $450 \mathrm{~kJ} / \mathrm{kg} \mathrm{W}^{0.75}$. A dose of $60 \mathrm{~g} P E G$ was given via the rumen cannulas and the same procedure and sampling times used as for the cows. Samples were obtained for analyses of PEG to estimate rumen volume and FRO and to determine the total $\mathrm{N}$ and $\mathrm{NH}_{3}$ contents.

Composition of nutrients. The volatile fatty acids (VFA) consisted of a mixture containing, on a molar basis, 65, 25 and 10 acetic, propionic and butyric acids respectively. They were diluted and then mixed with the major minerals before being directed to the rumen. The amounts of a buffer solution containing sodium and potassium bicarbonates and sodium chloride were adjusted to maintain rumen $\mathrm{pH}$ at between 6.2 and 6.5 . Trace minerals and vitamin requirements were supplied over the period when protein was withdrawn by direct injections through the abomasal catheter. Compositions of the infusates were described by MacLeod et al. (1982).

Analytical procedures. PEG was analysed in the rumen fluid using the method of Malawar \& Powell (1967), $\mathrm{N}$ was estimated by the method of Davidson et al. (1970) and $\mathrm{NH}_{3}$ by the method of Whitehead et al. (1967).

\section{Expt 2}

Animals and treatments. Four Friesian steers about 16 months old and with a range in live weight from 240 to $315 \mathrm{~kg}$ were used. They were fitted with rumen cannulas and abomasal catheters as described for the cows, and had been used to measure $\mathrm{N}$ loss at maintenance energy infusion. One steer was given a level of infusion of VFA calculated to supply $600 \mathrm{~kJ} / \mathrm{kg} \mathrm{W}^{0.75}$ and three steers were infused with VFA calculated to supply $450 \mathrm{~kJ} / \mathrm{kg} \mathrm{W}^{0.75}$. Before the measurements of $\mathrm{N}$ flow were made the animals had been given 
protein-free infusion for $4 \mathrm{~d}$. Three of the steers were given $60 \mathrm{~g}$ PEG and the fourth $70 \mathrm{~g}$ PEG as a pulse dose into the rumen to measure rumen volume and the FRO as for the cows in Expt 1. CrEDTA solution containing $18 \mathrm{~g} \mathrm{Cr} / \mathrm{l}(600 \mathrm{ml})$ was incorporated into the buffer solution to maintain a constant infusion rate over $24 \mathrm{~h}$ periods. Cr estimations were made in rumen and abomasal fluids. Flow rates from the rumen were calculated, and the flow rates from the abomasum derived from rumen flows and the ratio, $\mathrm{Cr}$ concentration in the rumen: $\mathrm{Cr}$ in abomasal fluid. The total liquid infused into the rumen was $32 \mathrm{litres} / \mathrm{d}$.

Analytical procedures. The same procedures were used for the analyses of $\mathrm{N}, \mathrm{NH}_{3}$ and PEG as for Expt 1. CrEDTA was prepared by the method of Downes \& McDonald (1964) and the $\mathrm{Cr}$ in rumen and abomasal fluid was determined by the technique of Stevenson \& de Langen (1960) and Mathieson (1970).

\section{Expt 3}

Animals and treatments. The objective for Expt 3 was to examine the effect of rumen $\mathrm{pH}$ and osmotic pressure on $\mathbf{N}$ flow through the digestive tract. Four male Suffolk cross lambs with a range in live weight of between 40 and $50 \mathrm{~kg}$ were used. The lambs were adapted to the infusion procedure as described in Expt 2. The composition of the VFA mixture infused into the rumen was the same as for Expts 1 and 2 and the level calculated to supply $450 \mathrm{~kJ} / \mathrm{kg} \mathrm{W}^{0.75}$. The lambs were infused for an initial $2 \mathrm{~d}$ on $\mathrm{N}$-free nutrients followed by an experimental period divided into three treatment periods of $2 \mathrm{~d}$. The treatment periods, although of short duration, were considered to be of sufficient time to reflect the changes that might occur (Hovell et al. 1983). In period 1 the rumen $\mathrm{pH}$ of all four lambs was maintained at approximately 6.5 . In period 2 the rumen $\mathrm{pH}$ of alternate lambs was held at 7.0 or 5.5 , and these $\mathrm{pH}$ levels were reversed for each of the treatment pairs in period 3. Rumen $\mathrm{pH}$ was maintained at the required level by altering the concentration of buffer solution infused, and was recorded continuously (MacLeod, 1983) and manually at two-hourly intervals.

PEG and CrEDTA were both continuously infused into the rumen in order to compare estimates of flow using either marker. The amount of CrEDTA used was equivalent to $3.4 \mathrm{~g} \mathrm{Cr} / \mathrm{d}$ together with $16 \mathrm{~g}$ PEG. The rumen and abomasal outflows were calculated as a product of the liquid infused and the ratio, PEG concentration infused:concentrations of PEG found at sampling time.

Measurements. About $20 \mathrm{ml}$ each of rumen and abomasal fluids were obtained at 09.00 , $11.00,14.00,17.00,23.00$ and 08.00 hours during the last $24 \mathrm{~h}$ of each treatment period. The $\mathrm{pH}$ of the samples was immediately recorded and the osmotic pressure (OP) measured using a model 3L Advanced Osmometer (Advance Instruments Inc., Massachusetts). Further analyses were made for $\mathrm{PEG}, \mathrm{Cr}, \mathrm{NH}_{3}-\mathrm{N}$ and $\mathrm{N}$ using the methods described earlier. When the series of observations was completed the rumen $\mathrm{pH}$ of all four animals was re-adjusted to between 6.2 and 6.5 by altering the concentration of the buffer infusate. $\mathrm{N}$-free infusions were continued and rumen and abomasal fluids withdrawn for amino acid analyses of the solids. Rumen and abomasal contents were withdrawn intermittently over a period of approximately $6 \mathrm{~h}$ to give a total amount of approximately 1.5 litres from each lamb. The fluids from all lambs were bulked and centrifuged for approximately $30 \mathrm{~min}$ at $1430 \mathrm{~g}$ using an MSE Minor bench centrifuge and the recovered solids freeze-dried. Rumen fluid contained more solids than did abomasal fluid, possibly due to calcium phosphate derived from the mineral infusate directed to the rumen. The method used for amino acid analysis was described by Storm et al. (1984). Methionine and cysteine were determined on oxidized samples using performic acid. Each sample was analysed in duplicate. For the main experiment the standard errors were calculated on a within-animal basis since there was no indication of significant animal or period effects. 
RESULTS

Expt 1

The rumen volume, $\mathrm{FRO}, \mathrm{NH}_{3}-\mathrm{N}$ and total $\mathrm{N}$ concentrations in the rumen, and the total flow of non- $\mathrm{NH}_{3}-\mathrm{N}(\mathrm{NAN})$ expressed on a daily basis and as a function of $\mathrm{W}^{0 \cdot 75}$ are given in Table 1.

The concentrations of total N and NAN were very similar for the steers and the cows. Due to large differences in size of the cows and steers there were obvious differences in rumen liquid volume and total flow but, expressed relative to $\mathrm{W}^{\mathbf{7} 75}$, the differences between the cows and the steers were small, although the number of animals involved cannot adequately assess the between-animal variability.

Table 1. The rumen volume, fractional rate of liquid outflow (FRO), nitrogen concentration, ammonia- $N$ concentration, and flow of non-ammonia- $N(N A N)$ out of the rumen of two pregnant cows and two steers receiving $N$-free nutrients on two separate occasions

\begin{tabular}{|c|c|c|c|c|c|c|}
\hline & \multirow[b]{2}{*}{ Rumen volume (l) } & \multirow[b]{2}{*}{ FRO } & \multicolumn{2}{|c|}{ Concentration of $\mathrm{N}$} & \multicolumn{2}{|c|}{ Total NAN flow } \\
\hline & & & Total N (mg/l) & $\mathrm{NH}_{3}-\mathrm{N}(\mathrm{mg} / \mathrm{l})$ & $\mathrm{g} / \mathrm{d}$ & $\mathrm{mg} / \mathrm{kg} \mathrm{W}^{0.25}$ \\
\hline \multicolumn{7}{|c|}{ Cows } \\
\hline 1 & 44.9 & 0.058 & 17.3 & $6 \cdot 1$ & $7 \cdot 0$ & 52.6 \\
\hline 2 & $52 \cdot 4$ & $0 \cdot 053$ & $13 \cdot 4$ & $6 \cdot 0$ & $4 \cdot 8$ & 38.0 \\
\hline 1 & $56 \cdot 8$ & 0.051 & 17.6 & $4 \cdot 2$ & $9 \cdot 3$ & 67.4 \\
\hline 2 & 67.5 & 0.049 & $21 \cdot 2$ & 5.9 & $12 \cdot 1$ & 44.7 \\
\hline \multicolumn{7}{|c|}{ Steers } \\
\hline 1 & $33 \cdot 4$ & $0 \cdot 058$ & $15 \cdot 3$ & 3.8 & $5 \cdot 3$ & $62 \cdot 2$ \\
\hline 2 & $39 \cdot 4$ & $0 \cdot 050$ & $14 \cdot 7$ & $3 \cdot 8$ & $5 \cdot 1$ & 56.9 \\
\hline 1 & $50 \cdot 2$ & 0.031 & $21 \cdot 2$ & $5 \cdot 5$ & 5.0 & $59 \cdot 3$ \\
\hline 2 & $51 \cdot 3$ & 0.032 & 16.2 & 3.7 & 4.9 & $54 \cdot 3$ \\
\hline
\end{tabular}

$\mathrm{W}$, live weight.

Expt 2

The results for the individual steers are given in Table 2, together with the standard deviations of the thirteen measurements of NAN and $\mathrm{NH}_{3}-\mathrm{N}$ concentrations. The standard deviations were calculated to indicate the extent of variability between the samples, since there was no systematic trend in the results to increase or decrease during the time of measurement. A comparison between the liquid flow rates derived from rumen volume and outflow rate from pulse-dose measurements, or from the concentrations of marker derived from the continuous infusate is given in Table 2 . The results are very similar, none of the differences being significant, though the values obtained were variable. The concentrations of NAN and $\mathrm{NH}_{3}-\mathrm{N}$ varied remarkably little during the $24 \mathrm{~h}$ indicated.

The flows of NAN through the rumen and abomasum were similarly calculated by the two methods described for liquid flows. The results derived by either method were almost identical, although highly variable between animals. The respective mean values and standard deviations of four observations on NAN flows through the rumen and abomasum were $(\mathrm{g} / \mathrm{d}): 6.0(1.4), 5.6(0.8) ; 13.4(4 \cdot 0), 13.5(4.0)$ or, as $\mathrm{mg} / \mathrm{kg} \mathrm{W}^{0.75}: 89 \cdot 5(23.5), 89.5$ $(23.5) ; 196 \cdot 1(47 \cdot 0), 194 \cdot 6(47 \cdot 0)$. Due allowance was made for $\mathrm{N}$ contained in CrEDTA.

\section{Expt 3}

The calculations of flow using CrEDTA were very similar to those obtained using PEG, and all the treatment differences observed were of the same magnitude. However, the 
Table 2. Expt 2. The liquid flow through rumen and abomasum calculated by two methods: (1) flows estimated from rumen volume and outflow rate and (2) from marker concentration differences in infusate, rumen and abomasum and the concentration of non-ammonia-nitrogen $(\mathrm{NAN})$ and $\mathrm{NH}_{3}-\mathrm{N}$ in rumen fluid and abomasal fluid of steers

(Mean concentrations of $\mathrm{N}$ are based on thirteen samples)

\begin{tabular}{|c|c|c|c|c|c|c|c|c|c|c|c|c|}
\hline \multirow[b]{3}{*}{ Method... } & \multirow{2}{*}{\multicolumn{2}{|c|}{$\begin{array}{l}\text { Liquid flow, } \\
\text { rumen }(\mathrm{l} / \mathrm{d})\end{array}$}} & \multirow{2}{*}{\multicolumn{2}{|c|}{$\begin{array}{l}\text { Liquid flow, } \\
\text { abomasum }(1 / d)\end{array}$}} & \multicolumn{4}{|c|}{$\begin{array}{l}\text { NAN concentration } \\
(\mathrm{mg} / \mathrm{l})\end{array}$} & \multicolumn{4}{|c|}{$\begin{array}{c}\mathrm{NH}_{3}-\mathrm{N} \text { concentration } \\
(\mathrm{mg} / \mathrm{l})\end{array}$} \\
\hline & & & & & \multicolumn{2}{|c|}{ Rumen } & \multicolumn{2}{|c|}{ Abomasum } & \multicolumn{2}{|c|}{ Rumen } & \multicolumn{2}{|c|}{ Abomasum } \\
\hline & 1 & 2 & 1 & 2 & Mean & SD & Mean & SD & Mean & SD & Mean & SD \\
\hline Steer 1 & $63 \cdot 7$ & $55 \cdot 4$ & $89 \cdot 8$ & $78 \cdot 7$ & $12 \cdot 4$ & $2 \cdot 1$ & $15 \cdot 4$ & 1.4 & $6 \cdot 3$ & 0.8 & $3 \cdot 6$ & 0.1 \\
\hline 2 & $44 \cdot 3$ & $52 \cdot 5$ & $63 \cdot 8$ & $75 \cdot 6$ & $10 \cdot 0$ & $1 \cdot 3$ & $13 \cdot 2$ & $2 \cdot 8$ & $6 \cdot 3$ & 0.9 & $3 \cdot 4$ & 0.5 \\
\hline 3 & $65 \cdot 4$ & $45 \cdot 0$ & $84 \cdot 3$ & $58 \cdot 0$ & $10 \cdot 2$ & 1.6 & $14 \cdot 1$ & $3 \cdot 8$ & $5 \cdot 8$ & $0 \cdot 6$ & $4 \cdot 6$ & 0.4 \\
\hline 4 & $77 \cdot 0$ & 92.9 & $109 \cdot 3$ & 131.9 & $6 \cdot 3$ & 0.4 & $17 \cdot 8$ & $0 \cdot 6$ & $9 \cdot 0$ & $1 \cdot 0$ & $4 \cdot 7$ & 0.3 \\
\hline Mean & $62 \cdot 6$ & $61 \cdot 4$ & $86 \cdot 8$ & $86 \cdot 1$ & $9 \cdot 7$ & $\ldots$ & $15 \cdot 1$ & - & 6.9 & - & $4 \cdot 1$ & - \\
\hline
\end{tabular}

Table 3. Expt 3. The effect of rumen $p H$ and osmotic pressure on rumen outflow, concentration of nitrogen and ammonia and passage of non- $\mathrm{NH}_{3}-\mathrm{N}(\mathrm{NAN})$ and $\mathrm{NH}_{3}$ and similar observations on the abomasal flows

(Each value is the mean of four observations)

\begin{tabular}{|c|c|c|c|c|}
\hline Rumen pH intended... & $5 \cdot 5$ & 6.5 & $7 \cdot 0$ & SE of means \\
\hline Rumen $\mathrm{pH}$ observed & $5 \cdot 68$ & $6 \cdot 38$ & $6 \cdot 92$ & 0.09 \\
\hline Rumen osmotic pressure (mosmol/1) & 288 & 288 & 373 & 25 \\
\hline Liquid infusate $(1 / 24 h)$ & $9 \cdot 9$ & $9 \cdot 9$ & $9 \cdot 9$ & - \\
\hline Rumen outflow (l/24h) & $7 \cdot 9$ & $5 \cdot 9$ & $9 \cdot 6$ & 0.94 \\
\hline Rumen N (mg/l) & 342 & 316 & 208 & 29 \\
\hline Rumen $\mathrm{NH}_{3}-\mathrm{N}(\mathrm{mg} / \mathrm{l})$ & 150 & 135 & 81 & 12 \\
\hline Outflow of rumen NAN $(\mathrm{g} / \mathrm{d})$ & $1 \cdot 50$ & $1 \cdot 08$ & $1 \cdot 20$ & 0.15 \\
\hline Outflow of rumen NAN $\left(\mathrm{mg} / \mathrm{kg} \mathrm{W}^{0.75}\right.$ per d) & 95 & 68 & 75 & 10 \\
\hline Abomasal pH & $2 \cdot 88$ & $3 \cdot 28$ & $3 \cdot 25$ & 0.49 \\
\hline Abomasal osmotic pressure (mosmol/l) & 263 & 264 & 299 & 12 \\
\hline Abomasal outflow $(1 / 24 \mathrm{~h})$ & $8 \cdot 8$ & $7 \cdot 7$ & $11 \cdot 4$ & 0.75 \\
\hline Abomasal $\mathrm{N}(\mathrm{mg} / \mathrm{l})$ & $41 \cdot 3$ & $52 \cdot 0$ & $28 \cdot 1$ & 49 \\
\hline Abomasal $\mathrm{NH}_{3}-\mathrm{N}(\mathrm{mg} / \mathrm{l})$ & $10 \cdot 2$ & $7 \cdot 0$ & $5 \cdot 0$ & 0.51 \\
\hline Abomasal NAN (g/d) & $2 \cdot 57$ & $3 \cdot 50$ & 2.63 & 0.43 \\
\hline Abomasal NAN (mg/kg W W $^{0.75}$ per d) & 160 & 221 & 163 & 27 \\
\hline
\end{tabular}

W, live weight.

estimates of flow from the rumen were on average $4.8 \%$ greater and from the abomasum $8.0 \%$ greater when CrEDTA was used as a marker. The difference between markers was significant $(P<0.05)$, and consistent with the finding that some CrEDTA was excreted in the urine and must have been absorbed from the rumen and abomasum. The differences were, however, small. PEG was not found in the urine. The results in the tables therefore relate to observations using $P E G$ as the marker.

The mean rumen $\mathrm{pH}, \mathrm{OP}$, rumen volume and outflow rate and concentration and outflow of $\mathrm{N}$ and $\mathrm{NH}_{3}-\mathrm{N}$ are given in Table 3. The mean rumen $\mathrm{pH}$ was close to the targeted $\mathrm{pH}$ of $5.5,6.5$ and 7.0 . The $\mathrm{OP}$ was higher at a $\mathrm{pH}$ of 7.0 than at $\mathrm{pH} 5.5$ and 6.5 . This difference 
Table 4. Amino acid ( $A A$ ) composition ( $\mathrm{g} / 16 \mathrm{~g}$ nitrogen) of rumen fluid and abomasal fuid from animals nourished by $N$-free intragastric nutrition in comparison with amino acid composition of whole wool-free empty-body in lambs (E. Storm and E. R. Ørskov, unpublished results)

\begin{tabular}{|c|c|c|c|}
\hline AA & Rumen isolates & Abomasal isolates & Whole empty-body \\
\hline Arginine & $5 \cdot 0$ & 3.7 & 8.4 \\
\hline Histidine & $2 \cdot 7$ & $2 \cdot 7$ & $2 \cdot 1$ \\
\hline Isoleucine & $3 \cdot 8$ & $3 \cdot 5$ & $3 \cdot 2$ \\
\hline Leucine & $7 \cdot 2$ & 3.6 & $6 \cdot 4$ \\
\hline Lysine & $6 \cdot 2$ & $5 \cdot 5$ & $6 \cdot 3$ \\
\hline Methionine & $1 \cdot 3$ & $1 \cdot 1$ & 1.8 \\
\hline Cysteine & $2 \cdot 1$ & $2 \cdot 4$ & $1 \cdot 0$ \\
\hline Phenylalanine & $4 \cdot 0$ & $3 \cdot 5$ & $3 \cdot 5$ \\
\hline Tyrosine & $3 \cdot 8$ & 3.7 & $2 \cdot 6$ \\
\hline Threonine & $4 \cdot 8$ & 4.9 & $3 \cdot 8$ \\
\hline Valine & $5 \cdot 0$ & $4 \cdot 6$ & $4 \cdot 1$ \\
\hline Essential AA & 45.9 & $39 \cdot 2$ & $44 \cdot 3$ \\
\hline Alanine & $4 \cdot 8$ & $4 \cdot 2$ & $5 \cdot 3$ \\
\hline Asparagine & $2 \cdot 4$ & 6.9 & 6.4 \\
\hline Glutamine & $12 \cdot 1$ & $9 \cdot 4$ & $12 \cdot 3$ \\
\hline Glycine & $4 \cdot 5$ & 4.8 & $7 \cdot 0$ \\
\hline Proline & 4.8 & 4.7 & $9 \cdot 3$ \\
\hline Serine & $4 \cdot 5$ & 4.9 & $4 \cdot 2$ \\
\hline Diaminopimelic acid & $0 \cdot 4$ & $0 \cdot 3$ & - \\
\hline Total AA & $79 \cdot 4$ & $74 \cdot 4$ & $89 \cdot 8$ \\
\hline Proportion of essential AA & 0.58 & 0.53 & 0.49 \\
\hline
\end{tabular}

approached significance $(P<0 \cdot 1)$. Outflow rates were greatest at the highest $\mathrm{pH}$ and the differences were significant $(P<0.05)$ between $\mathrm{pH} 6.5$ and 7.0 . Both rumen $\mathrm{N}$ concentration (corrected for $\mathrm{N}$ contained in CrEDTA) and the concentration of $\mathrm{NH}_{3}$ in the rumen were lower at $\mathrm{pH} 7$ than at $\mathrm{pH} 6.5$ and $5.5(P<0.01)$. There was no significant difference in rumen outflow of NAN when expressed as $\mathrm{g} / \mathrm{d}$ or as $\mathrm{mg} / \mathrm{kg} \mathrm{W}^{0.75}$ per $\mathrm{d}$.

The values relating to measurements on abomasal fluid are also given in Table 3 . Abomasal $\mathrm{pH}$ was not significantly altered by rumen $\mathrm{pH}$, but the $\mathrm{OP}$ of abomasal fluid was increased $(P<0 \cdot 1)$ when the rumen $\mathrm{pH}$ was 7.0 compared with the OP recorded at the two lower rumen $\mathrm{pH}$. The liquid flow from the abomasum was also increased $(P<0.05)$ at high rumen $\mathrm{pH}$ and $\mathrm{OP}$. The abomasal $\mathrm{N}(P<0.05)$ and abomasal $\mathrm{NH}_{3}-\mathrm{N}(P<0.001)$ concentrations decreased at the highest flow rate, i.e. when the rumen $\mathrm{pH}$ was $7 \cdot 0$ compared with 5.5 and 6.5 . Differences between abomasal $\mathrm{NH}_{3}$ concentrations at rumen $\mathrm{pH}$ of 5.5 and 6.5 were also significant $(P<0.01)$, although there was no significant difference between treatments in outflow of $\mathrm{N}$, whether it was expressed as $\mathrm{g} / \mathrm{d}$ or as $\mathrm{mg} / \mathrm{kg} \mathrm{W}^{0 \cdot 75}$ per d.

The correlation between rumen OP and outflow rates was $0.84(P<0.01)$. Although abomasal $O P$ varied much less than rumen $O P$, the correlation between rumen and abomasal $\mathrm{OP}$ was significant $(r<0.87, P<0.001)$. Increases in abomasal $\mathrm{pH}$ were reflected in an increased flow of $\mathrm{N}$ from the abomasum $(r<0.90, P<0.001)$.

The amino acid composition of the endogenous $\mathrm{N}$ from rumen and abomasal fluid is given in Table 4, together with a comparison with amino acid composition of whole wool-free empty body of lambs. The $\mathrm{N}$ content of the dry residue was 18.7 and $67.4 \mathrm{~g} \mathrm{~N} / \mathrm{kg}$ in rumen and abomasal contents respectively. The content of cysteine was found to be greatest in the endogenous $\mathbf{N}$. 


\section{DISCUSSION}

Rumen $\mathrm{NH}_{3}$ concentrations. Despite the fact that no protein was being infused into the rumen, the $\mathrm{NH}_{3}$ concentration in the fluid was consistently present. The concentrations appeared to be influenced by rumen $\mathrm{pH}$ as seen in Expt 3. It is not clear from the results if this decrease in $\mathrm{NH}_{3}$ concentration at a higher level of $\mathrm{pH}$ was a result of a decrease in entry of urea across the rumen wall or an increase in absorption rate. The fact that a substantial concentration of $\mathrm{NH}_{3}$ is maintained is of interest and may have some bearing on control mechanisms. Wallace et al. (1979) showed that rumen-wall bacteria were maintained in infused animals, and implied that since their ureolytic activity was dependent on or modified by rumen $\mathrm{NH}_{3}$ concentrations, they may be involved in the control of recycling of urea from the blood.

Flow of $N$. The NAN flowing from the rumen consists largely of epithelial cells derived from the respiratory tract, mouth and oesophagus, and the keratinized epithelial tissue from the rumen wall. It is likely that most of this $\mathrm{N}$ would be degraded to $\mathrm{NH}_{3}$ in the fed animal and thus be calculated as an endogenous source of $\mathrm{N}$ similar to urea. Varying amounts could also be degraded by adherent epithelial bacteria. About half the $\mathrm{N}$ in the abomasum appears to originate from the rumen. In the fed animal this may well be proportionately small, and in fact the average of 1-2 $\mathrm{g}$ abomasal $\mathrm{N}$ excretion/d determined by Clarke et al. (1966) in sheep may appear to be quite reasonable if it is assumed that the endogenous secretions in animals given normal diets are similar. On the other hand, Bergner et al. (1983) and Low \& Rainbird (1983) reported results with pigs in which the endogenous secretion increased with an increasing amount of bulk passing through the stomach. In the work of Bergner et al. (1983) grass was used to increase intake, while Low \& Rainbird (1983) used guar-gum.

Animal variability. It would appear from the present results that endogenous $\mathrm{N}$ secretion varied greatly between animals. The imposition of $\mathrm{N}$-free infusate prevented repeated observations on a within-animal basis, although the concentrations of $\mathrm{N}$ in the fluid during the hours of measurements were relatively constant. This was also reported by Harrop (1974), who observed that the $\mathrm{N}$ secreted into the fundic region of the abomasum of sheep varied from 0.5 to $2.5 \mathrm{~g} / \mathrm{d}$. The results suggest that if a constant value is assumed for endogenous contribution in the determination of dietary protein escaping degradation, very large errors must be expected (see discussion by Ørskov, 1982). The increase in $\mathrm{N}$ flow from the abomasum associated with increasing $\mathrm{pH}$ in the same organ is of interest and needs to be further investigated. It is possible that high flow rates and entry of VFA into the abomasum in large quantities may precipitate such a situation.

$O P$ in the rumen and flow of $N$. It is interesting to note here that rumen OP, while it affected liquid flow, had no consistent effect on $\mathrm{N}$ flow from the rumen, suggesting that epithelial shedding was controlled by factors other than liquid flow. When rumen OP were in excess of about $330 \mathrm{mosmol} / \mathrm{l}$ there was a net increase in liquid outflow from the rumen, but when the OP was lower there was an associated decrease in liquid outflow. This observation is in agreement with the results of Stacy \& Warner (1972), showing that at or about $350 \mathrm{mosmol} / 1$ there was a decrease in absorption rate of sodium and movement of water from the blood to the rumen.

PEG or CrEDTA as markers. Both markers were used in all experiments, but in some instances the colour of urine and a limited number of analyses indicated the presence of CrEDTA. Cr excreted in urine was not routinely estimated and we were therefore not able to quantify the amounts absorbed or to determine the overestimate of flow rates which may have occurred due to this discrepancy. Dobson et al. (1976), however, showed that in situations where rumen OP was increased $30-40 \mathrm{mosmol} / 1$ more than that in plasma there was a direct relation between absorption rate of CrEDTA and rumen hypertonicity. In Expt 
3 of the present work the concentrations of CrEDTA overestimated flow by $8 \%$ compared with flow rates derived using PEG. While this discrepancy is low, it would seem advisable to use PEG rather than CrEDTA in studies of liquid flow in ruminants, particularly if the treatment employed affected the OP since Sperber et al. (1957), in agreement with our results, never found traces of PEG in the urine.

Amino acid composition of rumen and abomasal content. The amino acid composition in the endogenous $\mathrm{N}$ uncomplicated by rumen bacteria and dietary $\mathrm{N}$ has probably not been obtained before in ruminants. It is interesting to note that the cysteine content is considerably greater in the endogenous $\mathrm{N}$, probably reflecting the content of keratinized epithelial cells from the rumen. It is also interesting that diaminopimelic acid is present in the contents which probably reflects the adherent bacteria on the rumen wall which was shown by Wallace et al. (1979) to be present in large numbers even with animals nourished by total intragastric infusion.

\section{REFERENCES}

Agricultural Research Council (1980). The Nutrient Requirements of Ruminant Livestock. Slough: Commonwealth Agricultural Bureaux.

Agricultural Research Council (1984). The Nutrient Requirements of Ruminant Livestock. Slough: Commonwealth Agricultural Bureaux.

Bergner, H., Bergner, V. \& Simon, O. (1983). Proceedings of the 4th International Symposium on Protein Metabolism and Nutrition, pp. 339-342. Clermont-Ferrand: INRA.

Clarke, E. M. W., Ellinger, G. M. \& Phillipson, A. T. (1965). Proceedings of the Royal Society, Series B 166, 63-79.

Davidson, J., Mathieson, J. \& Boyne, A. W. (1970). Analyst, London 95, 181-193.

Dinsdale, D., Cheng, K.-J., Wallace, R. J. \& Goodlad, R. A. (1980). Applied Environmental Microbiology 39, 1059-1061.

Dobson, A., Sellars, A. F. \& Gatewood, V. H. (1976). American Journal of Physiology 231, 1595-1600.

Downes, A. M. \& McDonald, I. W. (1964). British Journal of Nutrition 18, 1-11.

Harrop, C. J. F. (1974). Journal of Agricultural Science, Cambridge 83, 237-247.

Hovell, F. D. DeB., Orskov, E. R., MacLeod, N. A. \& McDonald, I. (1983). British Journal of Nutrition 50, 331-343.

Institut National de la Recherche Agronomique (1978). La Vache laitière. Theix, France: CRZV, INRA.

Low, A. G. \& Rainbird, A. L. (1983). Proceedings of the 4th International Symposium on Protein Metabolism and Nutrition, pp. 343-346. Clermont-Ferrand: INRA.

MacLeod, N. A. (1983). Research in Veterinary Science 34, 122-124.

MacLeod, N. A., Corrigall, W., Stirton, R. A. \& Ørskov, E. R. (1982). British Journal of Nutrition 47, 547-552.

Malawar, S. J. \& Powell, D. P. (1967). Gastroenterology 53, $250-256$.

Mathieson, J. (1970). Proceedings of the Nutrition Society 29, 30A.

Ørskov, E. R. (1982). Protein Nutrition in Ruminants. London and New York: Academic Press.

Orskov, E. R., Grubb, D. A., Wenham, G. \& Corrigall, W. (1979). British Journal of Nutrition 43, $553-558$.

Ørskov, E. R. \& MacLeod, N. A. (1982a). British Journal of Nutrition 47, 625-636.

Ørskov, E. R. \& MacLeod, N. A. (1982b). Proceedings of the Nutrition Society 41, 76A

Ørskov, E. R. \& MacLeod, N. A. (1983). Proceedings of the Nutrition Society 42, 61 A.

Sperber, I., Hyden, S. \& Ekman, J. (1957). Kungliga Lantbrugshogskolans Annaler 20, 337-344.

Stacy, B. D. \& Warner, A. C. I. (1972). Comparative Biochemical Physiology 43, 637-641.

Stevenson, A. E. \& de Langen, H. (1960). New Zealand Journal of Agricultural Research 3, 314-319.

Storm, E., Ørskov, E. R. \& Smart, R. I. (1984). British Journal of Nutrition 50, 471-478.

Wallace, R. J., Cheng, K.-J., Dinsdale, D. \& Ørskov, E. R. (1979). Nature 279, 424-426.

Whitehead, R., Cooke, G. H. \& Chapman, B. F. (1967). Automation in Analytical Chemistry, Technicon Symposium, vol. 2, p. 377. Basingstoke, Hants: Technicon Instruments Co. Ltd. 